\title{
Erratum: Social justice, corporate social responsibility and sustainable development in South Africa
}

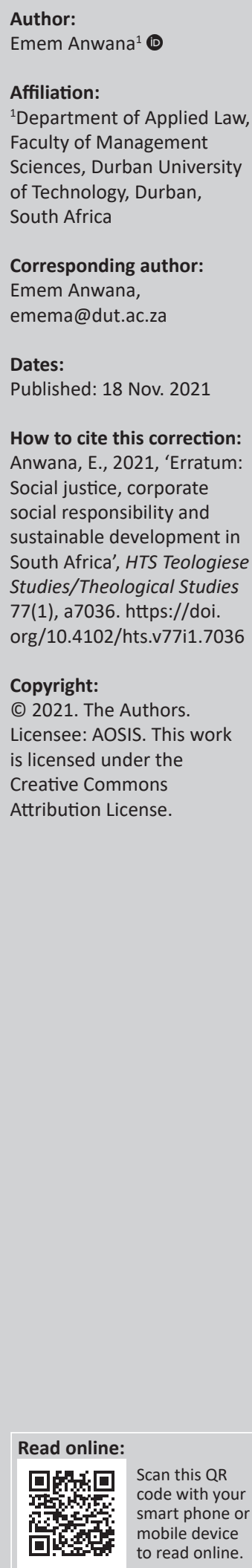

In the version of this article initially published, Anwana, E., 2020, 'Social justice, corporate social responsibility and sustainable development in South Africa', HTS Teologiese Studies/ Theological Studies 76(3), a6095. https://doi.org/10.4102/hts.v76i3.6095, the caption for Table 2 was given incorrectly. The correct caption should be 'Rotated component matrix indicating the variables that constitute factors that motivate South African businesses to implement corporate social responsibility' instead of 'Rotated component matrix $x^{a}$ indicating the variables that constitute the most challenges to South African businesses when implementing corporate social responsibility'.

This correction does not alter the study's findings of significance or overall interpretation of the study results. The publisher apologises for any inconvenience caused. 